\title{
EFEKTIVITAS PENERIMAAN PAJAK HOTEL DAN KONTRIBUSINYA TERHADAP PENINGKATAN PENDAPATAN ASLI DAERAH (PAD) KOTA MAKASSAR
}

\author{
Rualiaty ${ }^{1}$, Amran $^{2}$, Kasmida $^{3}$ \\ Universitas Muhammadiyah Makassar \\ Email: ${ }^{1}$ rulianty@unismuh.ac.id, ${ }^{2}$ amran@unismuh.ac.id, ${ }^{3}$ kasmida@unismuh.ac.id)
}

\begin{abstract}
This study aims to determine the effectiveness of hotel tax revenue and its contribution to the increase in Regional Original Income (PAD) of Makassar City, the type of research used in this study is quantitative descriptive research. Processed data is data obtained from interviews and financial statements in 2016. Data collection techniques used in this research are field studies, interviews and question and answer. Based on the results of this study it can be concluded that the overall contribution of hotel taxes in 2012-2016 contributed well to Regional Original Income (PAD) so that it can affect the number of PAD received. And from these results it can be seen that hotel taxes "greatly contribute" in increasing PAD in each year.
\end{abstract}

Keywords: Effectiveness, Hotel Tax, its contribution

\begin{abstract}
Abstrak
Penelitian ini bertujuan untuk mengetahui efektivitas penerimaan pajak hotel dan kontribusinya terhadap peningkatan Pendapatan Asli Daerah (PAD) Kota Makassar, jenis penelitian yang digunakan dalam penelitian ini adalah penelitian deskriptif kuantitatif. Data yang diolah adalah Data yang diperoleh dari hasil wawancara serta laporan keuangan tahun 2016. Teknik pengumpulan data yang digunakan dalam penelitian ini adalah studi lapangan, wawancara serta Tanya jawab. Berdasarkan hasil penelitian ini dapat disimpulkan secara keseluruhan kontribusi pajak hotel pada tahun 2012-2016 memberikan kontribusi yang baik terhadap Pendapatan Asli Daerah (PAD) sehingga dapat mempengaruhi jumlah PAD yang diterima. Dan dari hasil tersebut dapat diketahui bahwa pajak hotel "sangat berkontribusi" dalam meningkatkan PAD di tiap tahunnya.
\end{abstract}

Kata kunci : Efektivitas, Kontribusi, Pendapatan Asli Daerah (PAD) 


\section{PENDAHULUAN}

Otonomi daerah menghendaki daerah untuk berkreasi dalam mencari sumber penerimaan yang dapat membiayai pengeluaran pemerintah daerah dalam rangka menyelenggarakan pemerintah dan pembangunan. Dalam Undang-Undang Nomor 28 Tahun 2009 tentang pajak daerah dan retribusi daerah, pajak dan retribusi daerah merupakan dua sumber Pendapata Asli Daerah (PAD), disamping penerimaan dari kekayaan daerah yang dipisahkan serta PAD lain-lain yang sah. Semakin tinggi peranan PAD dalam pendapatan daerah merupakan cermin keberhasilan usaha-usaha atau tingkat kemampuan daerah dalam pembiayaan menyelenggarakan pemerintahan dan pembangunan.

Pendapatan Asli Daerah (PAD) merupakan sumber pendapatan daerah yang secara bebas dapat digunakan oleh masing-masing daerah untuk menyelenggarakan pemerintah dan pembangunan daerah. Oleh karenanya untuk mengurangi ketergantungan kepada pemerintah pusat, pemerintah daerah perlu berusaha meningkatkan Pendapatan Asli Daerah (PAD) yang salah satunya dengan penggalian potensi daerah.

Pajak daerah adalah sebagai salah satu komponen pendapatan asli daerah memiliki prospek yang sangat baik untuk dikembangkan. Oleh sebab itu pajak daerah harus dikelolah secara profesional dan transparan dalam rangka optimalisasi dan usaha meningkatkan kontribusinya terhadap anggaran pendapatan dan belanja daerah.

Pemerintah daerah kota Makassar merupakan salah satu daerah yang diberikan hak otonomi daerah untuk mengatur rumah tangganya sendiri. Seiring dengan berjalannya otonomi daerah, diharapkan pemerintah daerah mampu mengelola dan memaksimalkan sumberdaya yang ada di daerah untuk kelangsungan dan kemajuan daerah itu sendiri. Salah satu upaya pemerintah kota Makassar dalam meningkatkan Penerimaan Asli Daerahnya adalah melalui pajak daerah. Dimana salah satu sumber pendapatan daerah di kota Makassar yang berasal dari sektor pajak yaitu pajak hotel.

Pajak bagi pemerintah berperan sebagai sumber pendapatan (budgetary function) yang utama dan juga sebagai alat pengatur (regulatory function). Pajak sebagai salah satu sumber pendapatan daerah digunakan untuk membiayai pengeluaran - pengeluaran pemerintah, seperti membiayai administrasi pemerintah, membangun dan memperbaiki infrastruktur, menyediakan fasilitas pendidikan dan kesehatan, membiayai anggota polisi, dan membiayai kegiatan pemerintah daerah dalam menyediakan kebutuhankebutuhan yang tidk dapat disediakan oleh pihak swasta yaitu berupa barang-barang publik. Melihat dari fenomena tersebut dapat dilihat bahwa pentingnya pajak bagi suatu daerah, terutama dalam menyokong pembangunan daerah itu sendiri merupakan pemasukan dana yang sangat potensial karena besarnya penerimaan pajak akan meningkat seiring laju pertumbuhan penduduk, perekonomian dan stabilitas politik. Dalam pembangunan suatu daerah, pajak memegang peranan penting dalam suatu pembangunan.

Penarikan pajak di suat daerah disesuaikan dengan UU Nomor 28 Tahun 2009, sesuai dengan UU tersebut maka kabupaten atau kota diperkenankan untuk menarik pajak daerah. Pajak daerah adalah pajak yang ditetapkan oleh daerah untuk kepentingan pembiayaan daerah tersebut. Salah satu pajak daerah yang potensinya semakin berkembangan seiring dengan semakin diperhatikannya komponen sektor jasa dan pariwisata dalam kebijakan pembangunan sehingga dapat menunjang perkembangannya bisnis rekreasi (pariwisata) adalah pajak hotel. Sesuai dengan UndangUndang Nomor 28 Tahun 2009 pasal 1 angka 20 dan 21, pajak hotel adalah pajak atas layanan yang disediakan oleh hotel. 


\section{TINJAUAN PUSTAKA}

\section{Pengertian pajak}

Menurut UU No. 34 Tahun 2000 pajak daerah atau yang disebut pajak adalah iuran wajib yang dilakukan oleh orang pribadi atau badan kepada daerah tanpa imbalan langsung yang seimbang, yang dapat dipaksakan berdasarkan peraturan perundang-undangan yang berlaku, yang digunakan untuk membiayai penyelenggaraan pemerintah daerah dan penggunaan daerah.

Andriani dalam Waluyo (2013:2), Pajak adalah mengemukakan bahwa pajak adalah kontribusi wajib kepada negara yang terutang oleh orang pribadi atau badan yang bersifat memaksa berdasarkan Undang-Undang, dengan tidak mendapatkan imbalan secara langsung dan digunakan untuk keperluan negara bagi sebesar-besarnya kemakmuran rakyat.

Yolina (2009:11) mengemukakan bahwa pajak adalah iuran rakyat yang diberikan kepada kas negara beradasarkan undangundang (yang dapat dipaksakan) dengan tidak mendapatkan jasa timbal (kontraprestasi) yang langsung dapat ditunjukkan untuk membayar pengeluaran umum.

Mardiasmo (2011:1) menyatakan bahwa pajak adalah iuran rakyat kepada kas negara berdasarkan Undang-Undang (yang dapat dipaksakan) dengan tidak mendapat jasa timbal (kotraprertasi) yang langsung dapat ditunjukkan dan digunakan untuk membayar pengeluaran umum.

Dari pengertian diatas maka dapat ditarik kesimpulan, bahwa pajak adalah wajib rakyat kepada kas negara dengan memberikan kontribusi wajib kepada negara yang digunakan untuk melakukan pembangunan dan pengembangan dalam mencapai kesejahteraan seluruh rakyat Indonesia.

\section{Fungsi Pajak}

Pada umumnya fungsi pajak sebagai alat untuk politik perekonomian, pajak memiliki keuangan dan manfaat untuk meningkatkan kesejahteraan umum, suatu negara tidak mungkin menghendaki merosotnya kehidupan ekonomi masyarakat. Mordiasmo (2011:1) menyatakan bahwa fungsi pajak dibagi menjadi dua fungsi yaitu :

a. Fungsi Budgetair

Pajak sebagai sumber dana bagi pemerintah untuk membiayai pengeluaranpengeluarannya.

b. Fungsi regulered

Pajak sebagai alat untuk mengatur atau melaksanakan kebijaksanaan pemerintah dalam bidang sosial dan ekonomi.

\section{Sistem pemungutan pajak}

Sistem pemungutan pajak dibagi menjadi 3 sistem (Mardiasmo 2011:7) yaitu sebagai berikut :

a. Official assesment system

Suatu sistem pemungutan yang memberikan wewenang kepada pemerintah untuk menentukan besarnya pajak yang terutang oleh wajib pajak.

\section{b. Self-assestment system}

Suatu sistem yang memberikan wewenang sepenuhnya kepada wajib pajak untuk menghitung, membayar, dan melaporkan sendiri besar pajak yang terhutang.

\section{c. With holding assestment}

Suatu sistem pemungutan yang memberikan wewenang kepada pihak ketiga (bukan pemerintah dan bukan wajib pajak) untuk menentukan besarnya pajak yang terutang.

\section{Pendapatan Asli Daerah}

Secara garis besar pengertian Pendapatan Asli Daerah (PAD) yaitu hasil yang diperoleh pemerintah pusat yang dapat diukur dengan uang karena wewenangnya diberikan kepada masyarakat yang berupa hasil pajak daerah dan retribusi daerah, hasil perusahaan milik daerah dan pengelolaan kekayaan daerah serta pendapatan daerah lain-lain yang sah.

Berdasarkan UU No.33 tahun 2004 tentang perimbangan keuangan antara pemerintah 
pusat dan pemerintah daerah, PAD Bersumber dari :

\section{a. Penerimaan pajak daerah}

Pajak daerah adalah pungutan daerah menurut peraturan pajak yang ditetapkan oleh daerah untuk pembiayaan rumah tangganya sebagai badan hukum publik. Pajak daerah sebagai pungutan yang dilakukan pemerintah daerah yang hasilnya digunakan untuk pembiayaan pengeluaran umum pemerintah yang balas jasanya tidak secara langsung diberikan, sedang pelaksanaannya dapat dipaksakan.

b. Penerimaan retribusi daerah

Retribusi daerah merupakan pungutan yang secara sah menjadi pungutan daerah sebagai pembayaran pemakaian atau karena memperoleh jasa pekerjaan, usaha atau milik pemerintah daerah yang bersangkutan. Retribusi daerah mempunyai sifat-sifat : pelaksanaan bersifat ekonomis, ada imbalan langsung walaupun memenuhi persyaratanpersyaratan formulir dan materil, tetapi tetap ada alternatif untuk mau tidak mau membayar, merupakan pungutan yang pada umumnya bersifat budgetairnya tidak menonjol, dalam hal-hal tertentu retribusi daerah digunakan untuk sesuatu tujuan tertentu, tetapi dalam banyak hal retribusi daerah tidak lebih dari pengambilan biaya yang telah dikeluarkan oleh pemerintah daerah untuk memenuhi pemerintaan anggota masyarakat.

c. Hasil perusahaan milik daerah dan hasil pengelolaan kekayaan daerah yang dipisahkan

Yang disetor ke kas daerah, baik perusahaan hasil perusahaan milik daerah yang merupakan pendapatan daerah adalah keuntungan hasil perusahaan daerah yang berupa dana pembangunan daerah dan bagian untuk anggaran belanja daerah yang desetor ke kas daerah, baik perusahaan daerah yang dipisahkan, sesuai dengan motif pendirian dan pengelolaan, maka sifat perusahaan daerah, memberi jasa penyelenggaraan kemanfaatan umum,dan memperkembangkan perekonomian daerah.

d. Lain-lain pendapatan asli daerah yang sah

Lain yang tidak termasuk ke dalam jenisjenis pajak daerah dan retribusi daerah dan pendapatan dinas-dinas. Lain-lain usaha daerah yang sah mempunyai sifat pembuka kemungkinan bagi pemerintah daerah untuk melakukan berbagai kegiatan yang menghasilkan baik berupa materi dalam hal kegiatan untuk menunjang, melapangkan atau memantapkan suatu kebijakan pemerintah daerah suatu bidang tertentu. Beberapa macam lain-lain PAD yang sah yaitu sebagai berikut :

1) Hasil penjualan kekayaan daerah yang tidak dipisahkan

2) Jasa giro

3) Pendapatan bunga

4) Keuntungan selisih nilai tukar rupiah terhadap mata uang asing

\section{Pajak Daerah}

a. Pengertian pajak daerah

Mardiasmo (2011): menyatakan bahwa pajak daerah adalah iuran wajib yang dilakukan oleh orang pribadi atau badan kepala daerah tanpa imbalan langsung yang seimbang, yang dapat dipaksakan berdasarkan peraturan perundang-undangan yang berlaku, yang digunakan untuk membiayai penyelenggaraan pemerintah daerah dan pembangunan daerah.

Sedangkan, menurut UU Nomor 28 Tahun 2009 pasal 1 ayat 10: Pajak daerah adalah kontribusi wajib kepada daerah yang terutang oleh orang pribadi atau badan yang bersifat memaksa berdasarkan undang-undang, dengan tidak mendapatkan imbalan secara langsung dan digunakan untuk keperluan daerah bagi sebesar-besarnya kemakmuran rakyat.

Sesuai Undang-Undang No. 28 Tahun 2009 tentang pajak daerah dan retribusi daerah mengemukakan beberapa istilah yang terkait dengan pajak daerah sebagaimana tersebut dibawah ini : 
1) Daerah otonom, yang selanjutnya disebut daerah, adalah kesatuan masyarakat hukum yang mempunyai batas-batas wilayah yang berwenang mengaturdan mengurus urusan pemerintahan dan kepentingan masyarakat setempat menurut prakarsa sendiri berdasarkan aspirasi masyarakat dalam sistem nesara kesatuan republik Indonesia.

2) Pajak daerah, yang selanjutnya disebut pajak, adalah kontribusi wajib kepada daerah yang terutang oleh orang pribadi atau badan yang bersifat memaksa bedasarkan Undang-Undang, dengan tidak mendapatkan imbalan secara langsung dan digunakan untuk keperluan daerah bagi sebesar-besarnya kemakmuran rakyat.

3) Subjek pajak adalah orang pribadi atau badan yang dapat dikenakan pajak daerah.

4) Wajib pajak adalah orang pribadi atau badan, meliputi wajib pajak, pemotongan pajak, pemungut pajak, yang mempunyai hak dan kewajiban perpajakan sesuai dengan ketentuan peraturan perundangundangan perpajakan daerah.

b. Ciri-ciri pajak daerah

Ciri-ciri pajak daerah dapat diikhtisarkan yang dikemukakan sebagai berikut:

1) Pajak dipungut oleh negara, baik oleh pemerintah pusat maupun pemerintah daerah, berdasarkan kekuatan UndangUndang serta aturan pelaksanaannya.

2) Pembayaran pajak harus masuk pada kas negara, yaitu kas pemerintah pusat atau kas pemerintah daerah (sesuai dengan jenis pajak yang dipungut).

3) Dalam pembayaran pajak tidak dapat ditunjukkan adanya kontra prestasi individu oleh pemerintah (tidak ada imbalan langsung yang diperoleh pembayar pajak). Dengan kata lain, tidak ada hubungan langsung antara jumlah pembayaran pajak dengan kontra prestasi secara individu.

4) Penyelenggaraan pemerintah secara umum merupakan manifestasi kontra prestasi dari negara kepada para pembayar pajak.
5) Pajak dipungut karena adanya suatu keadaan, kejadian, dan perbuatan yang menurut peraturan perundang-undangan pajak dikenakan pajak.

c. Jenis dan tarif pajak daerah

Mardiasmo (2013:14) menyatakan bahwa jenis dan tarif pajak yang dapat dipungut oleh pemerintah daerah di atur dalam UU No. 34 Tahun 2000, yaitu jenis dan tarif pajak propinsi adalah sebagai berikut.

1) Pajak kendaraan bermotor dan kendaran di atas air 5\% (lima persen);

2) Bea balik nama kendaraan bermotor dan dan kendaraan di atas air 10\% (sepuluh persen);

3) Pajak bahan bakar kendaraan bermotor 5\% (lima persen);

4) Pajak pengambilan dan pemanfaatan air bahan tanah dan air permukaan $20 \%$ (dua puluh persen).

5) Jenis dan tarif pajak kabupaten/kota adalah sebagai berikut.

6) Pajak hotel 10\% (sepuluh persen);

7) Pajak restoran $10 \%$ (sepuluh persen);

8) Pajak hiburan $35 \%$ (tiga puluh lima persen);

9) Pajak reklame $25 \%$ (dua puluh lima persen);

10) Pajak penerangan jalan $10 \%$ (sepuluh persen);

11) Pajak pengambilan bahan galian golongan C 20\% (dua puluh persen);

12) Pajak parkir $20 \%$ (dua puluh persen).

\section{Tinjauan Empiris}

Berdasarkan penelitian yang dilakukan oleh Randy J.R. Walakandou (2013) yang berjudul "Analisis Kontribusi Pajak Hotel terhadap Pendapatan Asli Daerah (PAD)". Dalam membiayai pembangunan daerah, salah satu upaya pemerintah daerah adalah melalui sektor pajak. Hal demikian dilakukan oleh pemerintah kota Manado melalui Dispenda dalam melakukan usaha-usaha peningkatan pajak hotel untuk meningkatkan kas daerah 
untuk membiayai pembangunan. Penelitian ini dilakukan DISPENDA dikota Manado. Dispenda kota Manado adalah tempat untuk menyelenggarakan kewenangan pemerintah daerah dalam rangka desentralisasi dibidang pendapatan daerah, khususnya di kota Manado. Tujuan penelitian ini untuk mengetahui seberapa besar kontribusi pajak hotel terhadap PAD di kota Manado. Metode analisis yang digunakan adalah metode analisis deskriptif. Hasil dari penelitian ini yaitu pajak hotel memberikan kontribusi yang cukup besar kepada PAD kota Manado pada tahun 2007-2011 yaitu sebesar 5,60\% pada tahun 2007 5,38\%, pada tahun 2008 7,63\%, pada tahun $20098,11 \%$, pada tahun 2010 , dan 7,71\% pada tahun 2011 .

Berdasarkan penelitian yang dilakukan oleh Ni Nyoman Suartini (2011) yang berjudul "Pengaruh jumlah kunjungan wisatawan, pajak hiburan, pajak hotel dan restoran terhadap pendapatan asli daerah di kabupaten Gianyar". Tujuan dari penelitian ini adalah untuk mengetahui pengaruh secara serempak dan parsial jumlah kunjungan wisatawan, pajak hiburan dan PHR terhadap Pendapatan Asli Daerah (PAD) di Kabupaten Gianyar, dan mengetahui pengaruh dominan dari ketiga variable bebas terhadap PAD Kabupaten Gianyar. Data yang digunakan dalam penelitian ini adalah data sekunder, yang selanjutnya dianalisis dengan metode regresi linier berganda. Hasil dari penelitian ini menunjukkan bahwa jumlah kunjungan wisatawan, pajak hiburan, pajak hotel dan restoran berpengaruh signifikan terhadap PAD Kabupaten Gianyar. Dari nilai koefisien regresi terstandar menunjukkan nilai variabel PHR tertinggi, maka dapat disimpulkan PHR memiliki pengaruh paling dominan terhadap PAD Kabupaten Gianyar.

Berdasarkan penelitian yang dilakukan oleh Rizal yaya (2015), yang berjudul "Analisis implementasi dan kontribusi pajak hotel dan pajak restoran terhadap pendapatan asli daerah di kabupaten pulau Morotai". Tujuan dari penelitian ini adalah untuk mengetahui seberapa besar kontribusi dan efektivitas pajak hotel dan pajak restoran terhadap PAD di kabupaten pulau Morotai dan apa kendala yang dihadapi dalam pengelolaan pajak serta solusinya. Penelitian ini menggunakan metode deskriptif kuantitatif dan kualitatif. Berdasarkan hasil penelitian ini yaitu hasil menunjukkan rata-rata kriteria kontribusi cukup baik dan untuk analisis efektivitas ratarata kriterianya sangat efektif.

Berdasarkan penelitian yang dilakukan oleh Andi Arifwangsa Andiningrat, Subhan, Muhammad Nur (2017) yang berjudul "Analisis kontribusi pemungutan pajak hotel dan restoran terhadap pendapatan asli daerah di dispenda kota Makassar". Tujuan penelitian ini, untuk mengetahui seberapa besar kontribusi pemungutan pajak hotel dan restoran terhadap PAD kota Makassar. Pajak merupakan sumber penerimaan negara, yang menjadi salah satunya Pendapatan Asli Daerah (PAD) yaitu berasal dari pajak daerah, yang merupakan indikator penting yang dinilai sebagai tingkat kemandirian pemerintah daerah dibidang keuangan.Metode yang digunakan dalam penelitian ini adalah metode deskriftif yaitu menganalisis data realisasi pajak hotel dan pajak restoran. Hasil dari penelitian ini menunjukkan bahwa pajak hotel sangat kurang memberikan kontribusi sedangkan pajak restoran kurang memberikan kontribusi terhadap PAD pada tahun 2016.

Berdasarkan penelitian yang dilakukan oleh Edward W. Mewah (2013) yang berjudul "Efektivitas dan kontribusi penerimaan pajak hotel dan restoran terhadap PAD kota Manado". Tujuan dari penelitian ini untuk mengetahui tingkat efektivitas dan kontribusi pajak hotel dan restoran terhadap PAD kota Manado. Penelitian dilakukan di Dinas Pendapatan Daerah Kota Manado. Metode yang digunakan dalam penelitian ini yaitu metode deskriptif yaitu menganalisis data realisis pajak hotel dan restoran. Hasil dari penelitian ini yaitu menunjukkan bahwa 
tingkat efektivitas dari pajak hotel dan pajak restoran bervariasi. Tingkat efektivitas tertinggi pajak hotel terjadi pada tahun 2008 sebesar $116,32 \%$ dan terendah pada tahun 2011 sebesar 97,89 \%. Secara keseluruhan kontribusi pajak hotel dan pajak restoran pada tahun 2007-2011 memberikan kontribusi yang baik terhadap PAD. Presentase kontribusi pajak hotel terbesar tahun 2010 sebesar 8,11\% dan terendah tahun 2008 sebesar 5,38 \%.

Berdasarkan penelitian yang dilakukan oleh Garry A.G. Dotulong, David P.E. Saerang dan Agus T. Poputra (2014) yang berjudul "Analisis potensi penerimaan dan efektivitas pajak hotel di kabupaten Minahasa Utara". Tujuan dalam penelitian ini adalah menganalisis potensi penerimaan pajak hotel dan efektivita pajak hotel di kabupaten Minahasa Utara selama tahun 2010 hingga tahun 2012. Untuk mengetahui potensi penerimaan dan efektivitas dibutukan suatu data penelitian yang menggunakan runtun waktu. Metode yang dilakukan dalam penelitian ini adalah metode Kuantitatif deskriftif. Hasil dari penelitianya itu dapat dilihat dari perhitungan potensi penerimaan pajak hotel di daerah telah menunjukkan bahwa potensi pajak hotel belum tercapai secara optimal.

Berdasarkan penelitian yang dilakukan oleh Khairunnisa (2011), yang berjudul "Pajak hotel dan pajak restoran sebagai sumber Pendapatan Asli Daerah (PAD) (Studi kasus: kota Bandung)". Tujuan penelitian ini untuk menyusun strategi peningkatan potensi Pendapatan Asli Daerah (PAD) di kota Bandung dari sektor pajak hotel dan pajak restoran. Metode yang digunakan dalam penelitian ini adalah metode konsep Fred R. David, yaitu analisis Matriks Internal Factor Evaluation dan Matriks External Factor Evaluation (The Input Stage). Hasil dari penelitian ini adalah strategi yang dapat dilakukan dalam meningkatkan pendapatan dari pajak hotel dan pajak restoran adalah dengan meningkatkan promosi yang lebih efektif. Setelah itu dilakukan pengolahan seperti ketentuan yang digunakan oleh Fred R.

\section{METODE}

Penelitian ini termasuk dalam jenis penelitian deskriptif kualitatif, yaitu penelitian dengan mengumpulkan data - data, mengungkapkan dan memaparkan data dan mengintreprestasikan data. Penelitian ini mendeskripsikan realisasi dan potensi Pajak Hotel, menghitung efektifitas pemungutan Pajak Hotel dan menganalisis kontribusi Pajak Hotel terhadap Pendapatan Asli Daerah (PAD).

Lokasi penelitian yang dilakukan di Dinas Pendapatan Daerah (DISPENDA) kota Makassar dilaksanakan selama kurang lebih dua bulan Maret sampai Mei 2018.

Dalam penelitian ini menggunakan variabel yang terkait, antara lain sebagai berikut.

a. Pajak hotel adalah pajak atas pelayanan yang disediakan hotel. Sedangkan yang dimaksud dengan hotel adalah fasilitas penyedia jasa penginapan/ peristirahatan termasuk jasa terkait lainnya dengan dipungut bayaran, yang mencakup juga motel, losmen gubuk pariwisata, wisma pariwisata, pesanggrahan, rumah penginapan dan sejenisnya, serta rumah kos dengan jumlah kamar lebih dari sepuluh. Variabel ini diukur dalam satuan Rupiah.

b. Pajak restoran adalah pajak atas pelayanan yang disediakan oleh restoran. Sedangkan yang dimaksud dengan restoran adalah fasilitas penyediaan makanan atau minuman dengan dipungut bayaran, yang mencakup juga rumah makan, kafetaria, kantin, warung, bar dan sejenisnya termasuk jasa boga/ katering. Variabel ini diukur dalam satuan rupiah.

c. Efektivitas merupakan hubungan antara keluaran dengan tujuan atau sasaran yang harus dicapai. Dikatakan efektif apabila proses kegiatan mencapai tujuan dan sasaran akhir kebijakan (spending wisely). 
Semakin besar output yang dihasilkan terhadap pencapaian tujuan dan sasaran yang ditentukan, maka semakin efektif proses kerja suatu unit organisasi.

d. Kontribusi digunakan untuk mengetahui sejauh mana pajak daerah memberikan sumbangan dalam penerimaan PAD. Dalam mengetahui kontribusi dilakukan dengan membandingkan penerimaan pajak daerah (khususnya pajak hotel dan pajak restoran) periode tertentu dengan penerimaan PAD periode tertentu pula. Semakin besar hasilnya berarti semakin besar pula peranan pajak daerah terhadap PAD, begitu pula sebaliknya.

Populasi dari penelitian ini adalah pajak hotel dari suatu hotel. Sedangkan sampel dalam penelitian ini adalah pajak hotel Kota Makassar tahun 2015-2017. Teknik yang digunakan dalam penelitian ini adalah studi lapangan yang dilakukan di dinas pendapatan daerah yang merupakan objek penelitian, Sumber Data: DISPENDA Makassar

Sumbangsi pajak daerah terhadap PAD dari tahun 2012-2016 mengalami peningkatan pajak daerah memiliki penerimaan yang cukup tinggi dibandingkan dengan retribusi daerah, hasil pengelolaan daerah yang dipisahkan dan

Tabel 2. Perhitungan Efektifitas Pajak Hotel Tahun 2012-2016

\begin{tabular}{lllll}
\hline $\begin{array}{l}\text { Tah } \\
\text { un }\end{array}$ & Target (Rp) & $\begin{array}{l}\text { Realisasi } \\
\text { (Rp.) }\end{array}$ & $(\%)$ & $\begin{array}{l}\text { keteranga } \\
\mathrm{n}\end{array}$ \\
\hline 201 & 42.000 .362$. & 37.706 .161 & 89,78 & $\begin{array}{l}\text { Cukup } \\
2\end{array}$ \\
000 & .036 & $\%$ & Efektif \\
\hline 201 & 43.000 .000$. & 44.517 .581 & 103,5 & SangatEf \\
\hline
\end{tabular}

Sumber Data: DISPENDA Makassar

Dari tabel di atas dapat dilihat bahwa dalam tahun 2013 pajak hotel kota Makassar dapat mencapai target yand telah ditetapkan. Namun, dalam tahun 2012,2014,2015,2016 penerimaan pajak hotel tidak mencapai target yang ditetapkan yaitu pada tahun 2012 $89,78 \%$, tahun $201467,23 \%$, tahun 2015 $61,73 \%$ dan pada tahun $201651,04 \%$. Realisasi penerimaan pajak hotel yang terbesar untuk mendapatkan data diperlukan serta peninjauan langsung ke lokasi penelitian. Dalam studi lapangan ini penelitian dapat dilakukan dengan cara wawancara langsung yaitu dengan percakapan langsung serta tanya jawab dengan pihak dinas pendapatan kota Makassar mendapatkan data berupa daftar rincian peneriamaan pendapatan daerah kota makassar tahun 2015-2017.

\section{HASIL DAN PEMBAHASAN}

\section{Hasil}

Berikut ini adalah table Pendapatan Asli Daerah (PAD) Kota Makassar

Tabel 1. Pendapatan Asli Daerah

\begin{tabular}{llll}
\hline Tahun & Target (Rp) & Realisasi (Rp.) & $(\%)$ \\
\hline 2012 & 42.000 .362 .000 & 37.706 .161 .036 & $89,78 \%$ \\
\hline 2013 & 43.000 .000 .000 & 44.517 .581 .343 & $103,53 \%$ \\
\hline 2014 & 75.164 .615 .000 & 50.533 .548 .736 & $67,23 \%$ \\
\hline 2015 & 81.208 .967 .000 & 50.128 .251 .234 & $61,73 \%$ \\
\hline 2016 & 138.182 .620 .000 & 70.521 .682 .850 & $51,04 \%$ \\
\hline
\end{tabular}

lain-lain mendapatkan hasil daerah yang sah. Walaupun demikian penerimaan pajak daerah masi harus ditingkatkan penerimaannya. Khususnya pajak daerah dari sector pajak hotel.

\begin{tabular}{lllll}
\hline 3 & 000 & .343 & $3 \%$ & ektif \\
\hline 201 & 75.164 .615$. & 50.533 .548 & 67,23 & Kurang \\
4 & 000 & .736 & $\%$ & Efektif \\
\hline 201 & 81.208 .967$. & 50.128 .251 & 61,73 & Kurang \\
5 & 000 & .234 & $\%$ & Efektif \\
\hline 201 & 138.182 .620 & 70.521 .682 & 51,04 & Tidak \\
6 & .000 & .850 & $\%$ & Efektif \\
\hline
\end{tabular}

di tahun 2013 mencapai 103,53\% dan terendah terjadi di tahun 2016 sebesar 51,04\%. Tingkat efektivitas pajak hotel untuk tahun 2012-2016 dapat di kategorikan "kurang efektif" karena tidak mencapai target yang ditetapkanDi tahun 2012 tingkat efektivitasnya sebesar 89,78\% atau mengalami peningkatan $13,75 \%$ ke tahun 2013. Pada tahun 2013 tingkat efektivitasnya mengalami penurunan $36,3 \%$ ke tahun 2014 dan mengalami penurunan lagi di tahun 2015 
sebesar 5,5\%. Pada tahun 2015 mengalami penurunan lagi sebesar 10,69\% ke tahun 2016 . Hal ini disebabkan karena semakin menurunnya wajib pajak yang dapat melunasi kewajibannya tepat waktu. Setelah menghitung kontribusi pajak hotel dari tahun 2012-2016 dapat diketahui bahwa pajak hotel presentasi kontribusi terbesar beradapada tahun 2016 sebesar 8,02 \% dan presentasi terendah tahun 2012 sebesar $6,78 \%$ dengan rata-rata kontribusi $7,37 \%$.

\section{Pembahasan}

Berdasarkan analisis data yang dilakukan diperoleh dari Dinas Pendapatan Daerah Kota Makassar sesuai dengan hipotesis yang diajukan yaitu Diduga bahwa efektivitas penerimaan pajak hotel dan kontribusi pajak hotel berpengaruh terhadap peningkatan Pendapatan Asli Daerah (PAD) Kota Makassar masih kurang efektif, Di tahun 2012 dikatakan cukup efektif karena tingkat efektivitasnya $80 \%$ sebesar $89,78 \%$ atau mengalami peningkatan $13,75 \%$ ke tahun 2013. Pada tahun 2013 tingkat efektivitasnya di bawah 60\% dikatakan tidak efektif karena mengalami penurunan 36,3\%, ke tahun 2014 mengalami penurunan lagi karena tingkat pencapaiannya $60 \%$ di tahun 2015 sebesar 5,5\%. Pada tahun 2015 mengalami penurunan lagi sebesar 10,69\% ke tahun 2016 karena tingkat pencapaiannya di bawah $60 \%$. Hal ini disebabkan karena semakin menurunnya wajib pajak yang dapat melunasi kewajibannya tepat waktu.

Dari segi kontribusi, hipotesis yang diajukan yaitu Diduga bahwa efektivitas penerimaan pajak hotel dan kontribusi pajak hotel berpengaruh terhadap peningkatan Pendapatan Asli Daerah (PAD) Kota Makassar kontribusinya cukup besar, menunjukkan bahwa pajak hotel presentasi kontribusi terbesar beradapada tahun 2016 sebesar 8,02 $\%$ menunjukkan tingkat pencapaiannya $80 \%$ sehingga dikatakan cukup efektif dan presentasi terendah tahun 2012 sebesar 6,78\% dengan tingkat pencapaiannya $60 \%$ berarti kurang efektif dengan rata-rata kontribusi $7,37 \%$.

Hasil penelitian ini sejalan dengan penelitian terdahulu yang dilakukan oleh Edward (2013) melalui studi kasus di Dinas Pendapatan Daerah Kota Manado tentang efektivitas dan kontribusi penerimaan pajak hotel dan restoran terhadap PAD Kota Manado. Penelitian ini menghitung efektivitas dan kontribusi penerimaan pajak hotel dari tahun 2007-2011. Dari penelitia tersebut diperoleh hasil bahwa tahun 2007-2009 sngat efektif, di tahun 2010 efektif, sedangkan di tahun 2011 mempunyai tingkat efektivitasnya yang cukup efektif. Berdasarkan data tersebut diperoleh pula tingkat kontribusi yang dihasilkan. Pada tahun 2007-2011 semuanya tergolong sangat berkontribusi, tetapi kontribusi tersebut diperoleh di tahun 2010.

Berdasarkan data tersebut di atas diperoleh penerimaan pajak hotel dan tahun ke tahun mengalami fluktuatif. Hal ini menunjukkan bahwa sistem dan prosedur yang diterapkan belum efektif dilaksanakan. Dan semakin menurunnya jumlah wajib pajak yang membayarkan pajaknya tepat waktu meskipun ditiap tahunnya jumlah wajib pajak hotel bertambah ditiap tahunnya. Banyaknya jumlah target penerimaan pajak hotel yang ditetapkan oleh Dispenda Kota Makassar juga menjadi salah satu faktor penerimaan pajak hotel mengalami fliktuatif. Faktor yang menyebabkan perubahan kontribusi pajak hotel menurun dalam meningkatkan Pendpatan Asli Daerah (PAD) Kota Makassar pada tahun 2012-2016 yaitu, pertama tingkat hunian hotel yang masih rendah, adapun kualifikasi semuanya adalah hotel kelas melati atau hanya berbintang 1 dan 2, sehinga dapat dipahami tingkat hunian kamar hotel kurang berperan dalam realisasi penerimaan pendapatan asli daerah dan disebabkan karena tiap tahunnya target yang ditetapkan selalu meningkat seiring bertambahnya jumlah wajib pajak hotel di tiap tahunnya, tetapi proses penagihan terhadap penyetoran pajak yang dilakukan 
tidak berjalan baik sehingga jumlah realisasi tidak mencapai target.

\section{KESIMPULAN DAN SARAN}

\section{Kesimpulan}

Tingkat efektivitas pajak hotel untuk tahun 2012-2016 dapat di kategorikan "kurang efektif" karena tidak mencapai target yang ditetapkan. Di tahun 2012 tingkat efektivitasnya sebesar $89,78 \%$ atau mengalami peningkatan $13,75 \%$ ke tahun 2013. Pada tahun 2013 tingkat efektivitasnya mengalami penurunan $36,3 \%$ ke tahun 2014 dan mengalami penurunan lagi di tahun 2015 sebesar 5,5\%. Pada tahun 2015 mengalami penurunan lagi sebesar $10,69 \%$ ke tahun 2016 . Hal ini disebabkan karena semakin menurunnya wajib pajak yang dapat melunasi kewajibannya tepat waktu.

Secara keseluruhan kontribusi pajak hotel pada tahun 2012-2016 memberikan kontribusi yang baik terhadap Pendapatan Asli Daerah (PAD) sehingga dapat mempengaruhi jumlah PAD yang diterima. Dan dari hasil tersebut dapat diketahui bahwa pajak hotel "sangat berkontribusi" dalam meningkatkan PAD di tiap tahunnya.

\section{Saran}

Secara keseluruhan tingkat efektivitas dari pajak hotel thaun 2012-2016 kurang efektif, akan tetapi:

a. Sangat perlu perhatian dari pemerintah daerah untuk mengatur ketentuan yang jelas untuk mengatur target penerimaan pajak daerah terkhusus dari sector pajak hotel itu sendiri.

b. Instansi terkait dapat meningkatkan efektivitas dengan upaya meningkatkan kegiatan pendataan atau pendaftaran potensi sumber pajak.

c. Lebih meningkatkan upaya penagihan terhadap penyetoran yang belum di bayar (pembayaran yang menunggak), karena hal tersebut sangat mempengaruhi tingkat efektivitas yang dihasilkan. d. Semakin banyak wajib pajak dari sector hotel di tiap tahunnya, upaya penagihan pasti akan mengalami masalah. Oleh karena itu lebih baik membuka rekening khusus untuk wajib pajak hotel untuk menyetorkan pembayaran pajaknya, karena hal tersebut lebih efisien, dan tidak memakan banyak waktu.

\section{REFERENSI}

Adinigrat, Andi Arifwangsa dkk. 2017. Analisis Kontribudi Pemungutan Pajak Hotel dan Restoran terhadap Pendapatan Asli Daerah di Dispenda Kota Makassar. Jurnal Perspektif. Vol.02.

Casavera, 2009, Perpajakan, edisi pertama, cetakan pertama, Penerbit : Graha Ilmu, Yogyakarta.

Dotulong, G.A.G dkk. 2014. Analisis Potensi Penerimaan dan Efektivitas Pajak Restoran di Kabupaten Minahasa Utara. Jurnal Berkala Ilmiah Efesiensi. Vol.14.

Ilyas, W., Burton, R. 2011. Hukum pajak. Salemba Empat. Jakarta.

Khairunnisa. 2011. Pajak Hotel dan Pajak Restoran sebagai Sumber Pendapatan Asli Daerah (PAD) (Studi Kasus: Kota Bandung). Jurnal Perencanaan Wilayah dan Kota. Vol. 22.

Mahmudi. 2010. Analisis Laporan Keuangan Pemerintah Daerah. Sekolah Tinggi Ilmu Manajemen. Yogyakarta.

Mardiasmo. 2011. Perpajakan. Edisi Revisi. Penerbit Andi. Yogyakarta.

2012. Perpajakan, edisi revisi, cetakan kedelapanbelas. Penerbit: Andi. Yogyakarta.

Memah, E.W. 2013. Efektivitas dan Kontribusi Penerimaan Pajak Hotel dan Restoran terhadap PAD Kota Manado. EMBA. Vol.1.

Resmi, Sitti. 2007. Perpajakan dan teori kasus. Edisi 3. Salemba Empat. Jakarta. 
Siahaan, Marihot. 2009, Pajak Daerah dan Retribusi Daerah. Edisi Revisi. PT. Raja Grafindo Persada. Jakarta.

Suartini, Ni Nyoman dan Utama Made Suyana. 2011. Pengaruh Jumlah Kunjungan Wisatawan, Pajak Hiburan, Pajak Hotel dan Restoran terhadap Pendapatan Asli Daerah di Kabupaten Gianyar. Jurnal Perencanaan Wilayah dan Kota. Vol.22

Walakandou, R.J.R. 2013. Analisis Kontribusi Pajak Hotel terhadap Pendapatan Asli Daerah (PAD) di Kota Manado. EMBA. Vol.1.

Bardach, Eugene. (2004). Practical Guide For Policy: Analysis: Eighfild Paths toward Problem Solving, CQ Press, NY

Budiman Rusli. (2013). Kebijakan Publik: Membangun Pelayanan yang Responsif. Bandung: Hakim Publishing.

Fatmawati. (2016). Relationship Among Stakeholders for Solid Waste Management in Makassar. OSR Journal Of Humanities And Social Science (IOSR-JHSS) Volume 21, Issue 5, Ver. 5 (May. 2016) PP 18-23. 